\title{
RADIOCARBON AMS DATING OF POLLEN CONCENTRATED FROM EOLIAN SEDIMENTS: IMPLICATIONS FOR MONSOON CLIMATE CHANGE SINCE THE LATE QUATERNARY
}

\section{WEIJLAN ZHOU,}

National Laboratory of Loess and Quaternary Geology, Xi'an 710054 China

DOUGLAS DONAHUE and A. J. T. JULL

NSF-Arizona AMS Facility, University of Arizona, Tucson, Arizona 85721 USA

\begin{abstract}
Dating pollen concentrated from eolian sediments provides a new way to establish a chronological framework on the Loess Plateau of China. We show that pollen deposited simultaneously with sediment in a stable environment can provide reliable ages. We suggest that the reliability of pollen dating can be evaluated by comparison with wood cellulose or charcoal ages from the same stratigraphic level. Dating pollen concentrates from the various profiles indicates paleomonsoon precipitation variability at the loess/desert transitional belt from the late Pleistocene to the early Holocene.
\end{abstract}

\section{INTRODUCTION}

Loess-paleosol ${ }^{14} \mathrm{C}$ dating in the loess Plateau of China has been limited by the lack of suitable dating material. Previously, datable materials included mainly organic matter in soil, which generally provides a minimum age, owing to the presence of younger organic materials brought in by agriculture or atmospheric carbon incorporated through plant growth (Head, Zhou and Zhou 1989).

In this paper, we evaluate the use of fossil pollen as a dating material. Pollen concentrated from sediments can be dated on the basis of the following postulates. 1) Pollen is produced annually and deposited in situ in sediment; its exine or outer layer is composed of sporopollenin, which is very stable and does not exchange carbon with sediment. 2) Pollen undergoes limited translocation in loess-paleosol, $<10 \mathrm{~cm}$ (Wu et al. 1992), because at the loess/desert belt (which belongs to the arid steppe environment, with low annual precipitation and scarce vegetation cover), soil development is very weak, although mixing and percolation occur in the pedogenic process (Dimbleby 1985). 3) Pollen is an abundant plant fossil, well preserved in sediment, and accelerator mass spectrometry (AMS) technology allows the analysis of $<500 \mu \mathrm{g}$ of carbon. 4) Pollen is predominantly of terrestrial origin, and its age should not be influenced by reservoir effects (Regnell 1992).

Brown et al. $(1989,1992)$ showed that separation of pollen and pollen concentrates from lake sediments provides a dating material that is potentially superior to any sediment components used previously. Long, Davis and Lanois (1992) developed procedures for physically removing non-pollen contaminants from pollen concentrates, achieving high-precision dates. Based on their work, we developed and modified a procedure suitable for the extraction of pollen concentrate from eolian sediments.

\section{DESCRIPTIVE BACKGROUND}

This study focused on five profiles at the present northwestern margin of the Loess Plateau (Fig. 1), i.e., at the loess/desert transitional belt. Loess-mantled hills, sandy loess platforms (yuan) and seasonally flowing streams characterize the landscape of this area. In winter, the area has predominantly northerly and northwesterly winds, generating frequent dust storms. In summer, the main winds are southeasterly, moving inland off the ocean and producing $80 \%$ of the annual precipitation that falls as rainstorms (Zhang and Lin 1992). Mean annual temperature is $8^{\circ} \mathrm{C}$; mean annual precipitation is ca. $200-400 \mathrm{~mm}$. 


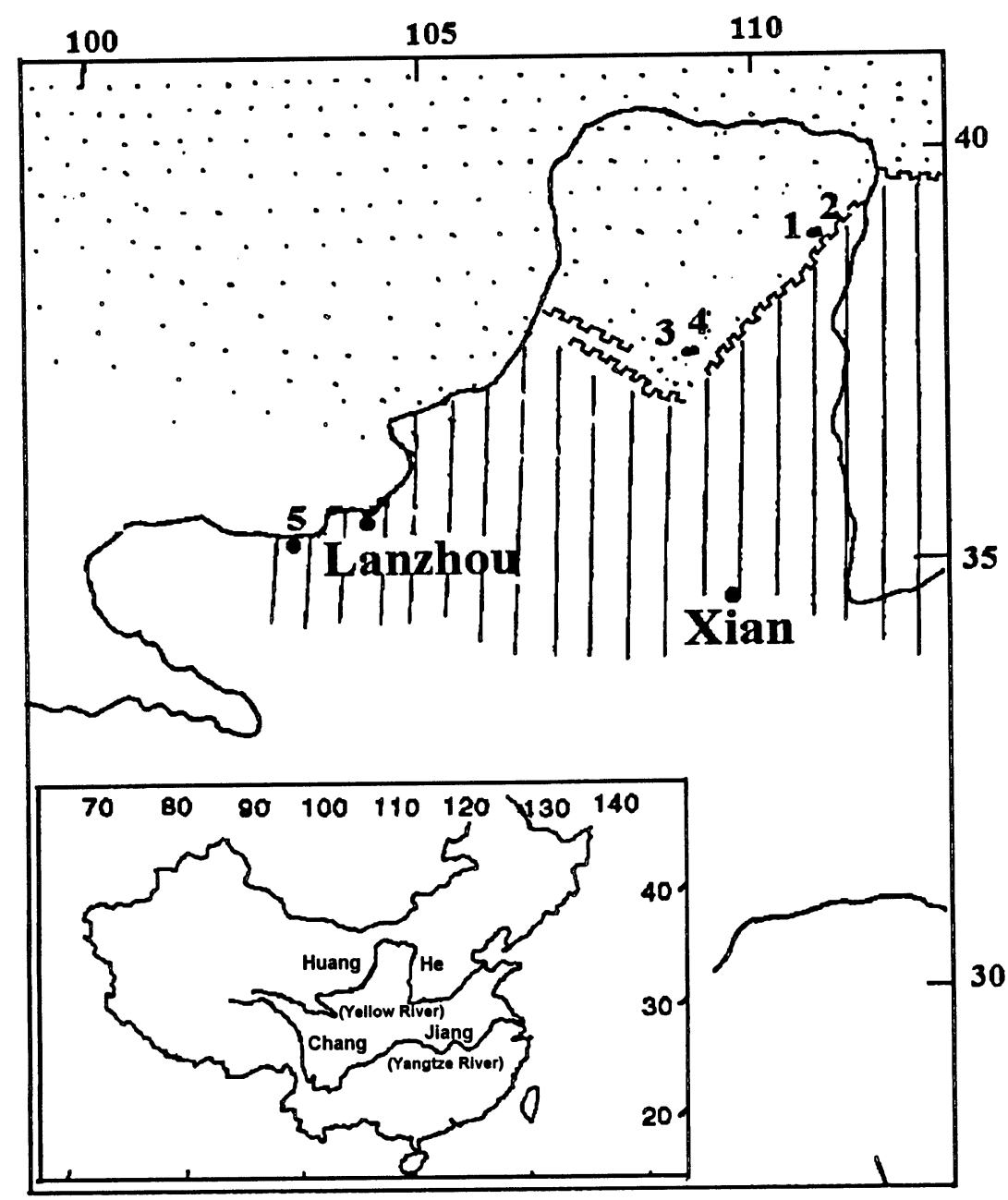

Fig. 1. Map showing study sites and the northern margin of the Loess Plateau. 1. Shiyaowan; 2. Yangtaomao; 3. Xuanheze; 4. Midiwan; 5. Baxie at the loess/desert transitional belt. The inset map shows China and the Yellow River.

The Xuanheze profile $\left(37^{\circ} 39^{\prime} \mathrm{N}, 108^{\circ} 37^{\prime} \mathrm{E}\right.$, at a mean elevation of $1400 \mathrm{~m}$ ) has a 500 -cm exposure of sediment (Figs. 1 and 2a). It is located on the second terrace of Xuanhe, a seasonal tributary of the Heiheze River, which is a second-order tributary of the Huanghe (Yellow River). The lowest $60 \mathrm{~cm}$ is a grayish-green silty mud. From 440 to $200 \mathrm{~cm}$ depth it is characterized by an eolian sand. Grayish-white marl occurs between 200 and $50 \mathrm{~cm}$ from the top of the sediment column. The top $50 \mathrm{~cm}$ consists of a grayish-green silty mud. The Midiwan profile (Fig. 1) occurs ca. $500 \mathrm{~m}$ to the east, located on the first terrace of Xuanhe River, with $1380 \mathrm{~cm}$ of peat sediment. Based on the ${ }^{14} \mathrm{C}$ chronology, peat deposition in the lake basin began ca. 13,000 BP, reflecting the onset of a warm-moist climate in the last deglaciation. Peat deposition reached maximum thickness $c a .10,000-7500 \mathrm{BP}$, during the Holocene Optimum. The section of the Midiwan profile is high-resolution and appears to be continuous. A detailed study of this profile has been given elsewhere (Zhou et al. 1996; Zhou 1995). 
The Yangtaomao profile $\left(38^{\circ} 48^{\prime} \mathrm{N}, 110^{\circ} 27^{\prime} \mathrm{E}\right.$, at a mean elevation of $\left.1400 \mathrm{~m}\right)$ consists of sand and interstratified paleosol exposed by wind erosion at the top of a loess-mantled hill (Zhou et al.1996). The section of the studied profile (Figs. 1 and 2c) consists of the upper $350 \mathrm{~cm}$, below which loess is found. From $350-315 \mathrm{~cm}$ is an immature sandy paleosol. Pale-yellow eolian sand at $315-157 \mathrm{~cm}$ depth contains a 38-cm-thick immature sandy paleosol (242-204 cm depth). The top $157 \mathrm{~cm}$ consists of a dark grayish-brown paleosol complex interstratified with an eolian sand layer 40-cm thick (78-38 cm depth). This soil complex consists of well-developed sandy steppe-type paleosol and is poorly consolidated. Located $c a .500 \mathrm{~m}$ to the west of the Yangtaomao section is a 2-m-thick exposure of the Shiyaowan profile (Figs. 1 and $2 \mathrm{~b})$. This section consists of eolian sand $(200-150 \mathrm{~cm})$ and grayish-brown paleosol $(150-0 \mathrm{~cm})$.

The Baxie loess section is located at the southwest margin of the Loess Plateau, $65 \mathrm{~km}$ southwest of Lanzhou $\left(35^{\circ} 33^{\prime} \mathrm{N}, 103^{\circ} 35^{\prime} \mathrm{E}, 2000 \mathrm{~m}\right.$ elevation), The stratigraphy of this profile was studied in detail by Zhou et al. (1992) and An et al. (1993). Here, we tried to redate one sample from the Baxie paleosol (where there was evidence for an increase of precipitation during the Younger Dryas interval), in order to compare dating of pollen concentrate with that of humic acid.

\section{Methods}

Separation of the pollen concentrates is based on both particle size and specific gravity (Table 1). Pollens from semi-arid to arid zones are mostly silt-sized. Before removing sand grains $(>40 \mu \mathrm{m})$ from the silt fraction by sieving, we used $5 \% \mathrm{HCI}$ to disaggregate carbonate clay. The mesh size of the sieve was also selected to eliminate organic detritus larger than most pollen. Then, we further

TABLE 1. Flowchart for Pollen Concentrate Preparation

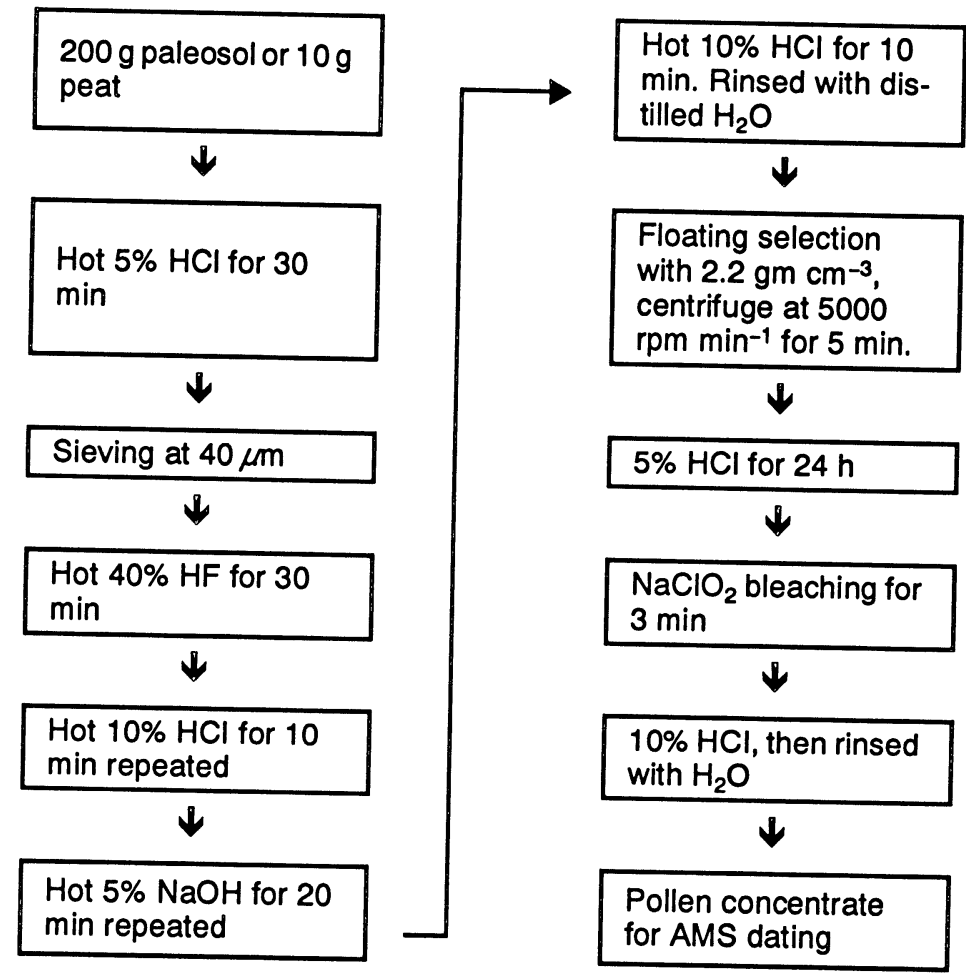


removed $\mathrm{CaCO}_{3}$ with $5 \% \mathrm{HCl}$, humic acid with $10 \% \mathrm{NaOH}$, and silica with $40 \% \mathrm{HF}$. Because pollen from semi-arid to arid zones ranges in specific gravity from 2.2 to 1.5 , we floated pollen out of the sediment using a heavy liquid $\left(\mathrm{KI}+\mathrm{HI}+\mathrm{Zn}\right.$ ) with a specific gravity (sp. gr.) of $2.2 \mathrm{~g} \mathrm{~cm}^{-3}$. The liquid was then diluted with water to sp. gr. of $<1.5$ to sediment the material. To increase pollen recovery, the extraction step was repeated twice, as sand, loess and paleosol are low in pollen compared to other sediments. Ke (1994) pointed out that flotation with a heavy liquid of sp. gr. ca. 2.2 is especially efficient for pollen extraction from loess-paleosol samples. Before we carried out the flotation method with a heavy liquid of sp. gr. 2.2, we tried the method proposed by Brown et al. (1992), but failed to extract enough pollen from eolian sand and paleosol for dating. Therefore, we developed a method combining particle size separation with floating in a heavy liquid, which enabled successful extraction of pollen from sand and paleosol. After pollen extraction, we found that our pollen concentrates consisted of 50\% pollen (mainly Artemisia and Chenopodiaceae), $45 \%$ phytoliths (considered to be a reliable alternative source for ${ }^{14} \mathrm{C}$ dating (Wilding 1967; Mulholland 1992)) and 0-5\% organic fragments. Careful microscope identification showed no soil fungi spores in the samples we studied. Because spores of soil fungi are the products of humid forest soil, generally they adhere to residues of higher plants (Cao 1980). Since the objective is to date the original carbon, any younger material adhering to the pollen particles must be removed. We used an oxidizer of $2 \% \mathrm{NaClO}_{2}$ for cleaning pollen concentrates. Because $\mathrm{NaClO}_{2}$ is a very strong oxidizer and destroys lignin and humic acids, but is also corrosive to pollen grains, we used the weak solution for a short period, e.g., no longer than $5 \mathrm{~min}$. Pollen samples were then treated further with $10 \% \mathrm{HCl}$, rinsed with distilled water and dried.

Ca. $500 \mathrm{mg}$ of extracted pollen concentrates was combusted in a sealed tube with $\mathrm{CuO}$. The $\mathrm{CO}_{2}$ was reduced to graphite (Slota et al. 1987) for AMS dating (Donahue, Jull and Zabel 1984).

\section{RESULTS AND DISCUSSION}

Pollen dating results from the various profiles are shown in Tables $2-4$. In order to evaluate the reliability of pollen concentrate dating, we re-collected four samples. Three samples are from the welldated Midiwan peat profile (Zhou et al. 1996), containing wood, charcoal, and peat (Table 2) and the others from Baxie paleosol for pollen concentrate dating. We can compare ages of wood cellulose and pollen (958 cm, 10,370 \pm 70 (AA-12190); 10,360 \pm 65 (AA-12186)), peat and pollen (1112 cm, $11,755 \pm 95$ (AA-16691); 11,765 \pm 80 (AA-12188)), and charcoal and pollen (1143 cm, 12,750 \pm 95

TABLE 2. AMS Result Comparison of Pollen Concentrates with Other Dating Material from Midiwan Peat and Baxie Loess Profiles

\begin{tabular}{lcll}
\hline Lab Code* & Depth $(\mathrm{cm})$ & Material dated & ${ }^{14} \mathrm{C}$ age $(\mathrm{yr} \mathrm{BP})$ \\
\hline AA-12190 & 958 & Wood cellulose & $10,370 \pm 70$ \\
AA-12186 $\dagger$ & 958 & Pollen concentrate & $10,360 \pm 65$ \\
AA-16691 & 1112 & Fine peat & $11,755 \pm 95$ \\
AA-12188 $\dagger$ & 1112 & Pollen concentrate & $11,765 \pm 80$ \\
AA-12196† & 1143 & Pollen concentrate & $12,390 \pm 100$ \\
AA-16393 & 1143 & Charcoal & $12,750 \pm 95$ \\
AA-16389 & 973 & Charcoal & $10,610 \pm 80$ \\
AA-6442 & 925 & Humic acid & $9695 \pm 95 \ddagger$ \\
M12566 & 925 & Pollen concentrate & $10,630 \pm 70 \ddagger$ \\
\hline
\end{tabular}

*AA- = NSF-AMS Facility, The University of Arizona

†Re-collected samples for pollen dating research

$\ddagger$ from Baxie loess profile 
(AA-16393); $12,390 \pm 100$ (AA-12196)). These values are in good agreement and indistinguishable within each pair within one standard deviation, indicating that pollen concentrate dating is reproducible. As for the Baxie paleosol (An et al.1993), which indicates a precipitation increase during the Younger Dryas on the Loess Plateau, the new pollen-concentrate age $(935 \mathrm{~cm}$ depth, 10,630 $\pm 70 \mathrm{BP}$ (AA-12566)) is ca. $900 \mathrm{yr}$ older than the previous humic-acid age (925 cm depth, $9695 \pm 95$ (AA6442)), although there is $10 \mathrm{~cm}$ difference in sample depth. The new pollen concentrate age on Baxie paleosol agrees with a recent charcoal age on the Midiwan peat, which is regarded as an indicator of increased precipitation in the mid Younger Dryas (AA-16389, 10,610 \pm 80 ; Zhou et al. 1996). This obviously suggests that pollen concentrate dating improves upon the age of humic acid from paleosol.

We applied this method to the chronology of these various profiles, with very interesting results (Tables 3 and 4; Fig. 2). Terrace two in the Xuanheze profile (Fig. 2a) shows that pollen concentrate ages form a good age sequence, except for one date from eolian sand: at $330 \mathrm{~cm}$ depth, AA-16120, the pollen concentrate dated $c a .10,000$ yr younger than the one above at $200 \mathrm{~cm}$ depth, AA-16119. Since the sand layer generally deposits rapidly, it is hard to believe that it took $c a .10,000 \mathrm{yr}$ for the deposition of $c a .250 \mathrm{~cm}$-thick sand. Accordingly, sample AA-16120 must contain younger pollen or organic detritus, and it should be discarded. The silty mud layer of the profile may correspond to the mud layer of the Beizhuangcun profile from the Loess Plateau $(28,400 \pm 340 \mathrm{BP}$, XLLQ28, Zhou, Zhou and Head 1990) and possibly further to the later oxygen isotope stage 3 of deep sea cores (Imbrie et al. 1984), reflecting cool and wet climatic conditions in East Asia. Moreover, we expect that dating of pollen concentrates from the Shiyaowan paleosol (Fig. 2b and Table 4) should provide reliable ages. These results generally agree with those from Midiwan peat (Zhou et al. 1996), indicating that warm and moist monsoon climate was favorable to paleosol development between $c a .11,680$ and 13,700 BP, during the climatic conditions of the last deglaciation.

TABLE 3. AMS Dating Result of Pollen from Xuanheze Eolian Sand-Paleosol Profile

\begin{tabular}{lcll}
\hline Lab code & Depth $(\mathrm{cm})$ & Material dated & ${ }^{14} \mathrm{C}$ age $(\mathrm{yr} \mathrm{BP})$ \\
\hline AA-16118 & 170 & Pollen concentrate & $27,910 \pm 330$ \\
AA-16119 & 200 & Pollen concentrate & $27,540 \pm 320$ \\
AA-16120 & 330 & Pollen concentrate & $17,315 \pm 130$ \\
AA-16121 & 490 & Pollen concentrate & $28,730 \pm 790$ \\
\hline
\end{tabular}

Table 4 and Figure $2 \mathrm{c}$ show pollen concentrate ages obtained from Yangtaomao paleosol and eolian sand. One sample at $158 \mathrm{~cm}$ depth gives a pollen concentrate age $\mathrm{ca} .3000 \mathrm{yr}$ too old, and another one at $258 \mathrm{~cm}$ depth is $c a .1600$ years too young, again providing evidence that pollen concentrated from eolian sand contains either younger or older materials. However, the rest of the six dates from paleosol have a good age sequence with depth and can be regarded as reliable. Microscopic examination combined with dating shows that pollen concentrate consists of two fractions: 1) pollen deposited simultaneously with sediment, and 2) reworked pollen including older (fossilized) spore pollen preceding sediment deposition in situ, or younger pollen transported through hydrological or agricultural activities; both younger and older pollen may come from either distant or local regions. Pollen reworking is generally an indicator of an unstable environment (Zhou et al. 1996).

The history of Asian monsoon variation at the loess/desert transitional belt at the end of the last glaciation has been reconstructed on the basis of the ${ }^{14} \mathrm{C}$ chronostratigraphy in Yangtaomao. The period from $c a$. 11,200 to $10,000 \mathrm{BP}$ (interpolated age) was dominated by a climate marked by cold and dry 

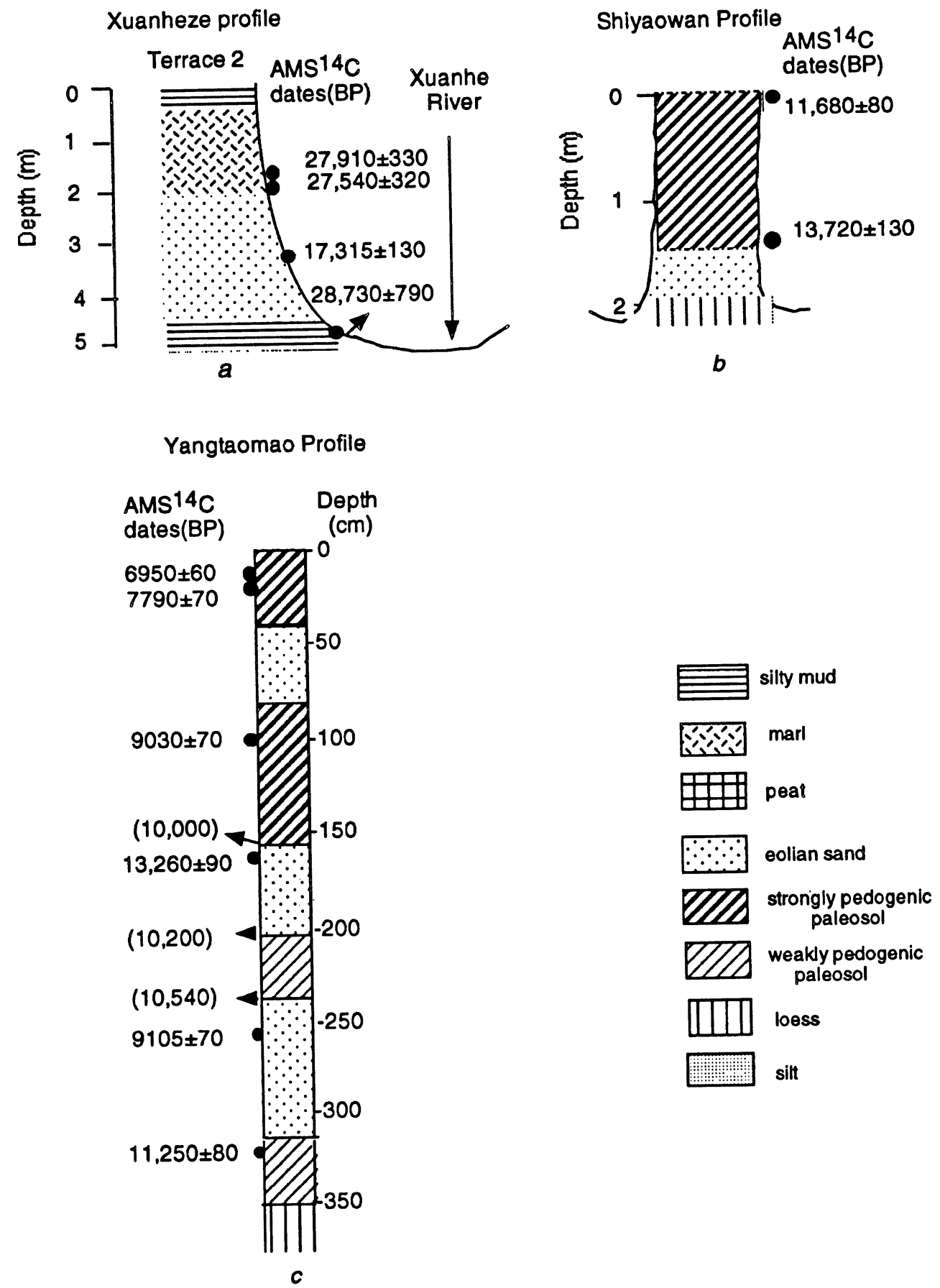

Fig. 2. (a) Xuanheze mud-eolian sand, (b) Shiyaowan loess-paleosol, and (c) Yangtaomao eolian sand-paleosol profiles, with AMS ${ }^{14} \mathrm{C}$ dates of pollen concentrate (Artemisia, Chenopodiaceae, Pinus, and organic residues). Ages in brackets are derived by interpolation. Dating of pollen concentrates extracted from paleosol or mud creates good age sequences with depth, except on those from eolian sand. Based on dating and lithology, several wet phases are marked by mud or paleosol around the late Pleistocene, last deglaciation, mid Younger Dryas and early Holocene. 
TABLE 4. AMS Dating Results of Pollen from Yangtaomao and Shiyaowan Eolian Sand-Loess-Paleosol Profiles

\begin{tabular}{lclc}
\hline Lab code & Depth $(\mathrm{cm})$ & Dating material & ${ }^{14} \mathrm{C}$ age $(\mathrm{yr} \mathrm{BP})$ \\
\hline AA-12317 & 11 & Pollen concentrate & $6950 \pm 60$ \\
AA-12311 & 22 & Pollen concentrate & $7790 \pm 70$ \\
$\mathrm{M}-12313$ & 102 & Pollen concentrate & $9030 \pm 70$ \\
$\mathrm{AA}-12315$ & 158 & Pollen concentrate & $13,260 \pm 90$ \\
AA-12312 & 258 & Pollen concentrate & $9105 \pm 70$ \\
AA-12316 & 325 & Pollen concentrate & $11,250 \pm 80$ \\
AA-12306* & 12 & Pollen concentrate & $11,680 \pm 80$ \\
M-12307* & 140 & Pollen concentrate & $13,720 \pm 130$ \\
\multicolumn{5}{l}{ "Samples collected from Shiyaowan profile }
\end{tabular}

winter monsoon during which $167 \mathrm{~cm}$ of eolian sand was deposited. However, the continued influx of an accretionary sandy soil suggests the continuation of strong winter monsoon conditions and increased precipitation. From 10,000-9000 BP, the well-developed paleosol reflects strengthening summer and weakening winter monsoon climates. A rapid decrease in the strength of the summer monsoon from ca. 9000 until $8000 \mathrm{BP}$, as recorded in the deposition of an eolian sand unit, indicates the return of the strong winter monsoon. After $c a .7000 \mathrm{BP}$, the profile was eroded. The late-glacial climatic oscillation evidence described here supports the pollen analysis results obtained from Midiwan profile (Zhou et al. 1996).

\section{Conclusion}

1. The comparison of ${ }^{14} \mathrm{C}$ ages of pollen concentrate with wood, charcoal, peat and paleosol humic acid clearly demonstrates that pollen dating provides useful age information for the Loess Plateau chronology. The newly obtained dating of pollen concentrate from the Baxie paleosol $(10,630 \pm 70$ $\mathrm{BP})$ agrees with charcoal dating of Midiwan peat $(10,610 \pm 80 \mathrm{BP})$. Our study shows that pollen concentrates may be a better material for dating paleosol than humic acid on the condition that pollen was deposited simultaneously with sediment in a stable sedimentary environment, such as pollen from paleosol or peat, whereas pollen preserved in an unstable environment (e.g., pollen from eolian sand or loess in an area where the winter monsoon is predominant and strong) does not necessarily provide reliable data. Therefore, a reliable chronology of the loess-paleosol sequence cannot be established without pollen separation, where suitable dating materials such as wood and charcoal are lacking. We intend to experiment further with loess-paleosol sequences for which detailed stratigraphic work has been done in order to improve the chronology of the Loess Plateau.

2. Four major wet phases have been dated from the Late Pleistocene to the early Holocene. Phase 1 is marked by lacustrine mud, which developed in Xuanheze ca. 29,000 yr BP; a similar sedimentary phase can be found in many locations on the Loess Plateau, reflecting a wet-cool climate (based on finding pollen of Abies and Pinus in Beizhuangcun mud (Zhou, Zhou and Head 1990)). In phase 2, ca. 13,700 BP, paleosol started to develop as shown in Shiyaowan, indicating the arrival of the last deglaciation. Phase 3 is recorded in Yangtaomao sandy paleosol $(10,500-10,200$ BP) during the Younger Dryas interval from 11,200 to $10,000 \mathrm{BP}$, indicating increased precipitation. In phase 4 , from 10,000 to $9000 \mathrm{BP}$, paleosol was well developed, reflecting warm-moist climatic conditions and arrival of the Holocene.

Precipitation variability is especially important for the understanding of paleomonsoon climate change at the loess/desert transitional belt of East Asia and can be used as a historic analog for cli-
mate prediction. 


\section{ACKNOWLEDGMENTS}

This study was supported by the Chinese National Science Foundation and U.S. National Science Foundation. The research staff of the NSF-Arizona AMS laboratory at the University of Arizona provided generous help in many ways.

\section{REFERENCES}

An, Z. S., Porter, S. C., Zhou, W. J., Lu, Y. C., Donahue, D. J., Head, M. J., Wu, X. H., Ren, J. Z., and Zheng, H. B. 1993 Episode of strengthened summer monsoon climate of Younger Dryas age on the Loess Plateau of central China. Quaternary Research 39: 45-54.

Brown, T. A., Nelson, D. E., Mathewes, R. W., Vogel, J. S. and Southon, J. R. 1989 Radiocarbon dating of pollen by accelerator mass spectrometry. Quaternary Research 32: 205-212.

Brown, T. A., Farwell, G. W., Grootes, P. M., and Schmidt, F. H. 1992 Radiocarbon AMS dating of pollen extracted from peat samples. In Long, A. and Kra, R. S., eds., Proceedings of the 14 th International ${ }^{14} \mathrm{C}$ Conference. Radiocarbon 34(3): 550-556.

Cao, S. G., 1980 Guidelines for Soil Micromorphology Study. Beijing, Agriculture Press (in Chinese).

Dimbleby, G. W. 1985 The Palynology of Archaeological Sites. New York, Academic Press: 176 p.

Donahue, D. J., Jull, A. J. T., and Zabel, T. H. 1984 Results of radioisotope measurements at the National Science Foundation / University of Arizona tandem accelerator mass spectrometer facility. Nuclear Instruments and Methods in Physics Research 219(B): 162166.

Head, M. J., Zhou, W., and Zhou, M. 1989 Evaluation of the ${ }^{14} \mathrm{C}$ ages of organic fractions from loess paleosol sequences near Xian, China. In Long, A., Kra, R. S. and Srdox, D., eds, Proceedings of the 13th International ${ }^{14} \mathrm{C}$ Conference. Radiocarbon 31(3): 680-694.

Imbrie, J., Hays, J. D., Martinson, D. G., Mclntyre, A., Mix, A. C, Morley, J. J., Pisias, N. G., Prell, W. L. and Shackleton, N. J. 1984 The orbital theory of Pleistocene climate: Support from a revised chronology of the marine ${ }^{18} \mathrm{O}$ record. In Berger, A., Imbrie, J., Hays, J., Kukla, G. and Saltzman, B., eds., Milankovitch and Climate (Part 1). Dordrecht, Reidel: 269-305.

Ke, M. H. 1994 A method of pollen-spore analysis in loess. Acta Botanica Sinica 36(2): 144-147.

Long, A., Davis, O. K., and Lanois, J. D. 1992 Separation and ${ }^{14} \mathrm{C}$ dating of pure pollen from lake sediments: Nanofossil AMS dating. In Long, A. and Kra, R. S., eds., Proceedings of the 14 th International ${ }^{14} \mathrm{C}$ Conference. Radiocarbon 34(3): 557-560.

Mulholland, S. C. and Prior, C. 1992 Processing of phytoliths for radiocarbon dating by AMS. Phytolitharian Newsletter 7(2): 7-9.

Regnell, J. 1992 Preparing pollen concentrates for AMS dating: A methodological study from a hard-water lake in southern Sweden. Boreas 21: 373-377.

Slota, P. J., Jull, A. J. T., Linick, T. W. and Toolin, L. J.1987 Preparation of small samples for ${ }^{14} \mathrm{C}$ accelerator targets by catalytic reduction of $\mathrm{CO}$. Radiocarbon 29(2): 303-306.

Wilding, L. P. 1967 Radiocarbon dating of biogenetic opal. Science 156: 66-67.

Wu, N. Q., Lu, H. Y., Nie, G. Z., Wang, Y. J., Meng, Y. and $\mathrm{Gu}, \mathrm{G}$. A. 1992 The study of phytoliths in $C_{3}$ and $\mathrm{C}_{4}$ grasses and its paleoecological significance. Quaternary Sciences 3: 241-251 (in Chinese).

Zhang, J. C., and Lin, Z. G. 1992 Climate of China. Trans. Tan, D. New York, John Wiley: 376 p.

Zhou, W. J., Zhou, M. F., and Head, M. J. $1990{ }^{14} \mathrm{C}$ Chronology of Beizhuangcun sedimentation sequence since 30,000 years B.P. Chinese Science Bulletin 35(7): 567-572.

Zhou, W. J., An, Z. S., Lin, B. H., Xiao, J. Zhang, J. Z., Xie, J., Zhou, M. F., Porter, S. C., Head, M. J. and Donahue, D. J. 1992 Chronology of the Baxie loess profile and the history of monsoon climates in China between 17,000 and 6000 years BP. In Long, A. and $\mathrm{Kra}, \mathrm{R}$. S., eds. Proceedings of the 14th International ${ }^{14} \mathrm{C}$ Conference. Radiocarbon 34(3): 818-825.

Zhou, W. J., Donahue, D. J., Porter, S. C., Jull, A. J. T., Li, X. Q. Stuiver, M., An, Z. S., Matsumoto, E., and Gong, G. R. 1996 Variability of monsoon climate in East Asia at the end of last glaciation. Quaternary Research, in press.

Zhou, W. J. (ms.) 1995 Monsoon climate change in the environmentally sensitive zone of inland China in the last $13,000 \mathrm{yr}$ and its ${ }^{14} \mathrm{C}$ chronology. Ph.D dissertation, Northwest University, Xian, China. 